Engineering Hydrology 


\section{Engineering Hydrology}

E. M. WILSON, PH.D., M.SC., F.I.C.E.

Department of Civil Engineering

University of Salford

Macmillan Education 
(C) E. M. Wilson 1969 Softcover reprint of the hardcover 1st edition 1969

First Published in 1969

Published by MACMILLAN AND CO LTD Little Essex Street London wc2 and also at Bombay Calcutta and Madras Macmillan South Africa (Publishers) Pty Ltd Johannesburg The Macmillan Company of Australia Pty Ltd Melbourne The Macmillan Company of Canada Ltd Toronto

ISBN 978-1-349-00331-0

ISBN 978-1-349-00329-7 (eBook) DOI 10.1007/978-1-349-00329-7 


\section{Preface}

This book has been written for engineering students who are learning what hydrology is about, and also for the many junior engineers in design offices who know something about the subject but need to know more, and who require quantitative answers. Some texts on hydrology make a virtue of avoiding all mathematics. They do so at the expense of being practically useless to the engineering profession. At the other end of the scale are the advanced papers being written by the theoretical hydrologists. They are continually extending and developing the subject, often by the use of advanced mathematical techniques. Between these two extremes the practising engineer and advanced student need a text-book which reminds them of the fundamentals, shows how theory must be modified in practice and describes the techniques for producing answers in particular cases.

Most texts fulfilling these requirements are American in origin, rather expensive, and exclusively based on N. American data and practice. There seems to be a need for a more European approach, at a lower price, which though it must rely heavily on American development of hydrology, uses British and European authorities with greater freedom and indigenous data for its examples. This book attempts to meet that need.

The text is written using S. I. units as far as possible. It is not always possible, since many empirical formulae and coefficients are only known in the ft-lb-sec system. The result is a mixture of the two, though each calculation is consistent throughout. This use of the two systems is perhaps an advantage in disguise. Over the next five years British engineers will have to learn to live with and use 
both systems. Europeans have already learned to do this in hydrology, because of the preponderance of N. American publications. American readers may be assured that one becomes 'bi-lingual' very rapidly.

Any comparatively short text-book is a compromise between comprehensiveness and brevity. The present volume is based on the amount of material that can usefully be absorbed by final year undergraduates in two hours a week, during one academic year, with time for practical example computation, and yet touching on all important topics with particular emphasis on hydrograph analysis, stream-flow routing and forecasting methods.

My thanks are due to the many people who helped with criticism, advice and the provision of data, and with the inevitable typing and production problems.

E. M. WILSON 


\section{Contents}

Introduction

1.1 Allied sciences

1.2 The hydrological cycle

1.3 Hydrology as applied in engineering

2 Meteorological Data

2.1 Weather and climate

2.2 Humidity

2.3 Temperature

2.4 Precipitation

2.5 Forms of precipitation other than rain

2.6 The extension and interpretation of data

3 Evaporation and Transpiration

3.1 Meteorological factors

3.2 Transpiration

3.3 Methods of estimating evaporation 
3.4 Evaporation from land surfaces using Penman's $E_{0}$ value

3.5 Thornthwaite's formulae for evapo-transpiration

3.6 Direct measurement of evaporation by pans

3.7 Consumptive use

\section{Infiltration and Percolation}

4.1 Infiltration capacity of soil

4.2 Factors influencing $f_{p}$

4.3 Methods of determining infiltration capacity

4.4 The effect of soil moisture

5 Groundwater

5.1 The occurrence of groundwater

5.2 Factors of influence

5.3 Groundwater flow

5.4 The abstraction of groundwater

5.5 The yield of wells

6 Surface Runoff

6.1 The engineering problem

6.2 Flow rating curves: their determination, adjustment and extension

6.3 Duration of runoff

6.4 Catchment characteristics and their effect on runoff

6.5 Climatic factors

6.6 Rainfall/runoff correlation

7 Hydrograph Analysis

7.1 Components of a natural hydrograph

7.2 The contribution of baseflow to stream discharge 
Contents

ix

7.3 Separation of baseflow and runoff

7.4 The unit hydrograph

7.5 Unit hydrographs of various durations

7.6 The unit graph as a percentage distribution

7.7 Derivation of the unit hydrograph

7.8 Unit hydrograph from complex or multi-period storms

7.9 The instantaneous unit hydrograph

7.10 Synthetic unit hydrographs

8 Flood Routing

8.1 Introduction

8.2 The storage equation

8.3 Reservoir routing

8.4 Routing in a river channel

8.5 Graphical routing methods

8.6 Synthetic unit graphs from flood routing

\section{Hydrological Forecasting}

9.1 Introduction

9.2 Flood formulae

9.3 Frequency analysis

9.4 Rainfall data and the unit hydrograph

9.5 Hydro-meteorology

9.6 Periodicity in hydrologic phenomena

Penman's Nomogram

Facing page 170

General Bibliography

171

Index

178 